\title{
POPULATION VIABILITY AND MANAGEMENT RECOMMENDATIONS FOR WILD WATER BUFFALO Bubalus bubalis IN KOSI TAPPU WILDLIFE RESERVE, NEPAL
}

\author{
Joel T. Heinen* \\ School of Natural Resources, University of Michigan, Ann Arbor, Michigan 48109-1115, USA
}

(Received 11 March 1991; revised version received 25 October 1992; accepted 27 October 1992)

\begin{abstract}
Population characteristics, breeding structure, and sources of mortality of wild water buffalo Bubalus bubalis were studied in Kosi Tappu Wildlife Reserve, a small reserve located in the southeastern lowlands of Nepal, during 1987 and 1988. Comparisons with an earlier census indicated that the population was growing over a 12-year time interval. However, observations on the physical nature of the reserve and known seasonal movements of buffalo suggested that the population is not viable for several reasons. Most morality observed during the study took place over the rainy season, suggesting that flooding was the major source; half of the first-year calves disappeared during that time. Because the reserve was subject to extensive flooding during the rains, buffalo regularly left to reside in cane and sugar fields. Hence the reserve did not include the annual home range of any buffalo herds. In addition, thousands of domestic cattle and hundreds of domestic buffalo used the reserve illegally, which posed a risk of disease to wild water buffalo. Management recommendations, including a reintroduction of the species into Royal Chitwan National Park, are made in light of the analysis.
\end{abstract}

Key words: Nepal, wild water buffalo.

\section{INTRODUCTION}

With the passage of the 1973 National Parks and wildlife conservation act (Anon., 1977), Nepal began an era of committing resources for the conservation of species and protected areas. The Act and subsequent amendments now give full protection to 26 mammals, eight bird, and three reptile species. Of primary concern to wildlife professionals is how policies and management practices can lead to the long-term survival of these endangered populations in increasingly isolated, fragmented landscapes such as those found in South Asia (e.g. Seshadri, 1986; Heinen \&

* Present address: FREE, 4900 25th Street NE, Suite 201, Seattle, WA 98105, USA.

Biological Conservation 0006-3207/93/\$06.00 (C) 1993 Elsevier Science Publishers Ltd, England. Printed in Great Britain
Kattel, 1992). As Goodman (1987) pointed out, studying management measures and reserve-design features for small, fragmented populations is desirable for estimating and enhancing population viability; several field studies (e.g. Mwalyosi, 1991; Yonzon \& Hunter, 1991) have shown that reserve characteristics, as well as conflicts with local people, can influence long-term viability of populations.

In this study, the population growth rate, sources of mortality, population structure, seasonal movements, and important aspects of social behavior relevant for conservation of wild water buffalo Bubalus bubalis were studied over a 1.5 year period (November 1986 to March 1988) in Kosi Tappu Wildlife Reserve, a small reserve located in southeastern Nepal. This species was studied because it is protected in Nepal and elsewhere and is presently limited to this single isolated population within the country. There is no immigration or emigration and the species is highly polygynous, so this example readily points out the problem inherent to maintaining adequate effective breeding population sizes $\left(N_{\mathrm{e}}\right)$ for many large mammals. Furthermore, the population was studied in two different time periods (Dahmer, 1978, and the present study), which allowed comparison of the instantaneous population growth rates at different times.

\section{THE SPECIES AND STUDY AREA}

Wild water buffalo are ancestral to domestic water buffalo widely used as dairy and draught animals in Asia and parts of North Africa and Europe (Cockrill, 1974). Evidence of domestication goes back 4500 years (Clutton-Brock, 1989), when the species ranged from Mesopotamia to Indochina (Sinclair, 1977). Wild water buffalo historically occurred throughout much of the lowland parts of South Asia in suitable riverine forests and grasslands but are now considered endangered throughout their range. Several large populations are found in Indian reserves such as Kaziranga National Park in Assam and Indravati Wildlife Sanctuary in Madya Pradesh (Saharia, 1982), but the species has been extirpated from large portions of its former range. The current worldwide population is now estimated at 
several thousand individuals, which does not include the Australian population founded from domestic stock originating in Southeast Asia (Tulloch, 1974, 1978, 1979), or the large feral population in Indonesia (Halder, 1973). Despite the importance of this species in domestication, there is very little published information on the basic biology or conservation status of the wild form.

Water buffalo are highly social animals, and females remain in the groups in which they were born. Adult males live either as resident bulls in mixed herds comprised of females and their dependent offspring, or as bachelors, either singly or in herds. Tulloch (1978) reported that in northern Australia female clans of feral Buffalo occasionally join to form herds of up to 500 animals. Such concentrations have not been observed in wild water buffalo although a herd of domestic buffalo was observed joining a wild herd on three occasions during the present study. This general social structure is common to many large ungulates (Schaller, 1977), but is in contrast to the closely related tamarao B. mindorensis, a smaller species which tends to be a solitary forest-dweller (Kuehn, 1986).

Within Nepal, wild water buffalo were recorded as recently as the early 1960 s in what is now Royal Chitwan National Park in the central lowlands, but they were extirpated from that area presumably as a result of diseases carried by domestic cattle and buffalo (Seidensticker, 1975). Kosi Tappu Wildlife Reserve (approx. $170 \mathrm{~km}^{2}$ ) contains the last Nepalese population. The reserve was established in 1976 and is located on the floodplain of the Sapt Kosi River in Sunsari, Saptari and Udayapur Districts in southeastern Nepal (elevation 75-100 $\mathrm{m}$ above mean sea level). The entire reserve is subject to flooding during the summer rains, and buffalo and other ungulates frequently leave the area at that time and seek refuge in croplands. About $70 \%$ of the land area is dominated by tall grasses such as species of Saccharum, Phragmites and Typha. Mixed forests of Bombax, Dalbergia and Acacia make up the remainder. The vegetation was investigated by Dahmer (1978), who found it to be characteristic of riverine communities in the monsoonal climate of the Gangetic Basin as described by Stainton (1972).

\section{METHODS}

I observed herds of wild water buffalo in Kosi Tappu from January 1987 to March 1988. Records of home range, movements, population structure, habitat use, and social behavior were regularly recorded during the dry seasons (January -June 1987 and November 1987March 1988). This was accomplished by walking two different set routes in the reserve twice a week each, which allowed me to relocate each mixed herd, one male herd, and several solitary males twice per week. Another male herd and the remaining solitary males were relocated once per week along the eastern boundary road by spot-lighting from a vehicle. The rainy season in 1987 was characterized by extreme flooding in the reserve, making regular observations difficult, although I was able to record some home range data for that period as well.

The portion of the data considered here includes calf and adult mortality, population size, herd composition, and home range observations. A mixed herd is composed of one resident bull, females, and their dependent offspring. Non-breeding bulls occur either alone or in bachelor herds. The instantaneous growth rate of the population was determined by the formula:

$$
r=\frac{\ln \left(N_{1} / N_{2}\right)}{t_{1}}
$$

\section{RESULTS}

The population structure for 1976 (from Dahmer, 1978), 1987 and 1988 (this study) are reported in Table 1. The age structure of the population reported by Dahmer was probably incorrect because he counted 22 secondyear animals in 176 in a population of only 18 adult females, and buffalo-like most artiodactyls (Bronson, 1989) - do not normally produce twins (Bhattacharya, 1974; Tulloch, 1979). Many of the males classed as second-year in that study were probably third-year, or older, individuals (Table 2). However, Dahmer's overall population figures were considered accurate, and aging first-year individuals is generally much less difficult because they are distinctly smaller and lighter in color than older animals. For these reasons, calculating $r$ from Dahmer's data was possible although the reported age structure may have been incorrect.

The instantaneous population growth rate was calculated for (1) 1976-1988, (2) 1976-1987, and (3) 1987-1988. A comparison of these values is important for determining variation in $r$ over time. The instantaneous population growth rate over the entire time period was rather high $(0.0325)$ although this was lower than that calculated for African buffalo during a recovery phase (Sinclair, 1977); the value was higher

Table 1. The population structure of wild water buffalo in Kosi Tappu Wildlife Reserve in 1976 (from Dahmer 1978), 1987 and 1988

\begin{tabular}{|c|c|c|c|c|c|c|c|}
\hline \multirow[t]{2}{*}{ Year } & \multicolumn{2}{|c|}{ Adults } & \multirow[t]{2}{*}{ 2nd year } & \multirow[t]{2}{*}{ 1st year } & \multirow[t]{2}{*}{ Total } & \multirow[t]{2}{*}{ Calves/cows } & \multirow[t]{2}{*}{$r^{\mu}$} \\
\hline & Male & Female & & & & & \\
\hline 1976 & 12 & 18 & 22 & 11 & 63 & 0.61 & $r_{\text {Tot }}=0.0325$ \\
\hline 1987 & 32 & 29 & 14 & 16 & 91 & 0.55 & $r_{1}=0.0334$ \\
\hline 1988 & 37 & 33 & 8 & 15 & 93 & 0.45 & $r_{2}=0.0217$ \\
\hline
\end{tabular}

${ }^{a}$ Where $r_{\text {Tot }}$ is the population growth rate of the entire time period, $r_{1}$ is the population growth rate for 1976 to $1987, r_{2}$ is the population growth rate for 1987 to 1988 . 
Table 2. Census comparisons of wild water buffalo for herds and single animals counted in 1976 and 1988

\begin{tabular}{|c|c|c|c|c|c|c|}
\hline Herd/year & $\begin{array}{c}\text { Adult } \\
\text { females }\end{array}$ & $\begin{array}{l}\text { Adult } \\
\text { males }\end{array}$ & $\begin{array}{c}\text { 3rd-year } \\
\text { males }\end{array}$ & $\begin{array}{l}\text { 2nd-year } \\
\text { totals }\end{array}$ & $\begin{array}{l}\text { 1st-year } \\
\text { totals }\end{array}$ & Totals \\
\hline \multicolumn{7}{|l|}{ South herd } \\
\hline 1976 & 3 & 1 & - & 2 & 3 & 9 \\
\hline 1988 & 16 & 1 & - & 3 & 7 & 27 \\
\hline \multicolumn{7}{|l|}{ North herd } \\
\hline 1976 & 15 & 1 & - & 13 & 8 & 37 \\
\hline 1988 & 17 & 1 & 4 & 5 & 8 & 35 \\
\hline \multicolumn{7}{|l|}{ Male herds } \\
\hline 1976 & & 9 & & $7^{a}$ & & 16 \\
\hline \multicolumn{7}{|l|}{1988} \\
\hline Herd 1 & & 12 & & & & 12 \\
\hline Herd 2 & & 12 & & & & 12 \\
\hline \multicolumn{7}{|l|}{ Single males } \\
\hline 1976 & & 1 & & & & 1 \\
\hline 1988 & & 7 & & & & 7 \\
\hline \multicolumn{7}{|l|}{ Totals } \\
\hline 1976 & & & & & & 63 \\
\hline 1988 & & & & & & 93 \\
\hline
\end{tabular}

${ }^{a}$ Dahmer (1978) estimated the age of these subadults at just under two years. They were probably older (see text).

for the time period 1976-1987 than for the last year of the study (Table 1). Making long-term comparisons was not possible because there were no good censuses prior to the 1976 study. Dahmer (1978) reported several different censuses prior to this time, but concluded that those results could not be used because in several cases the observers could not reliably distinguish between wild water buffalo and domestic backcrosses, a chronic problem in Kosi Tappu (see above).

Table 2 shows a breakdown of the number of animals in the population by herds and solitary individuals. It is interesting to note that the two mixed herds identified here were also described by Dahmer (1978), and their seasonal home ranges overlapped with those recorded twelve years earlier (Fig. 1). The male groupings, however, were more ephemeral; herd sizes varied more, and the figures given are for the greatest number seen at one time within a herd. Young males (judged by horn size; see Dahmer, 1978) were always seen in groups, but older bachelors were more often solitary, suggesting that the tendency for males to group diminishes with age. Also note that several third-year males remained with the north herd in 1988 , in contrast to Dahmer (1978), who stated that males as young as 1.5 years left the mixed herds. Longer term studies are needed to observe the dynamics of herding behavior in these and other ungulates.

Flood-related mortality was the only mortality source recorded by Dahmer (1978), who witnessed the deaths of two individuals during his study. During my study, $50 \%$ (eight out of 16) of the first-year calves and three adult females disappeared during and shortly after the 1987 rainy season. Two of the three missing adult females had first-year calves. No yearlings of either sex disappeared during the floods.

Discharge data obtained from the Kosi Barrage, a low dam located $6 \mathrm{~km}$ south of the study area, indi- cated that there were two large floods in 1987, one during the last week of August, and one during the third week of October. A first-year calf was found dead at the Barrage during the first week of September (after the first flood), and another was found trapped in mud and was rescued by reserve staff in late October (after the second flood). Although not conclusive, these observations suggest that the missing females and calves died during floods, or as a result of flooding. Two adult males also died during the course of the study. One was judged from its poor physical appearance to be very old ( $>12$ years), and it died in mid-July 1987 prior to any major floods. The other died in January 1988 as a result of injuries sustained during a fight with another male. These results indicate that flooding is the most important source of mortality for calves, and may also be for adult females, but not for males.

\section{DISCUSSION}

The results of this study raise several concerns for the management of wild water buffalo in Nepal. The primary one is that practices must be engaged such that the overall population size, and hence presumably the effective population size, will increase. There is currently little direct evidence of inbreeding depression in wild vertebrate populations (Angus \& Schultz, 1983), and Dinerstein and McCracken (1990) have shown that genetic diversity can be maintained after recovery from a bottleneck in at least one large mammal population (Indian rhinoceros Rhinoceros unicornis in Nepal). However, Soule (1980) has recommended that an $N_{\mathrm{e}}$ of at least 50 , corresponding to a per generation rate of inbreeding of 0.01 (Falconer, 1981), is needed to avoid the immediate deleterious effects of inbreeding.

During the course of this study, within each dry season, only one adult male was regularly observed with 


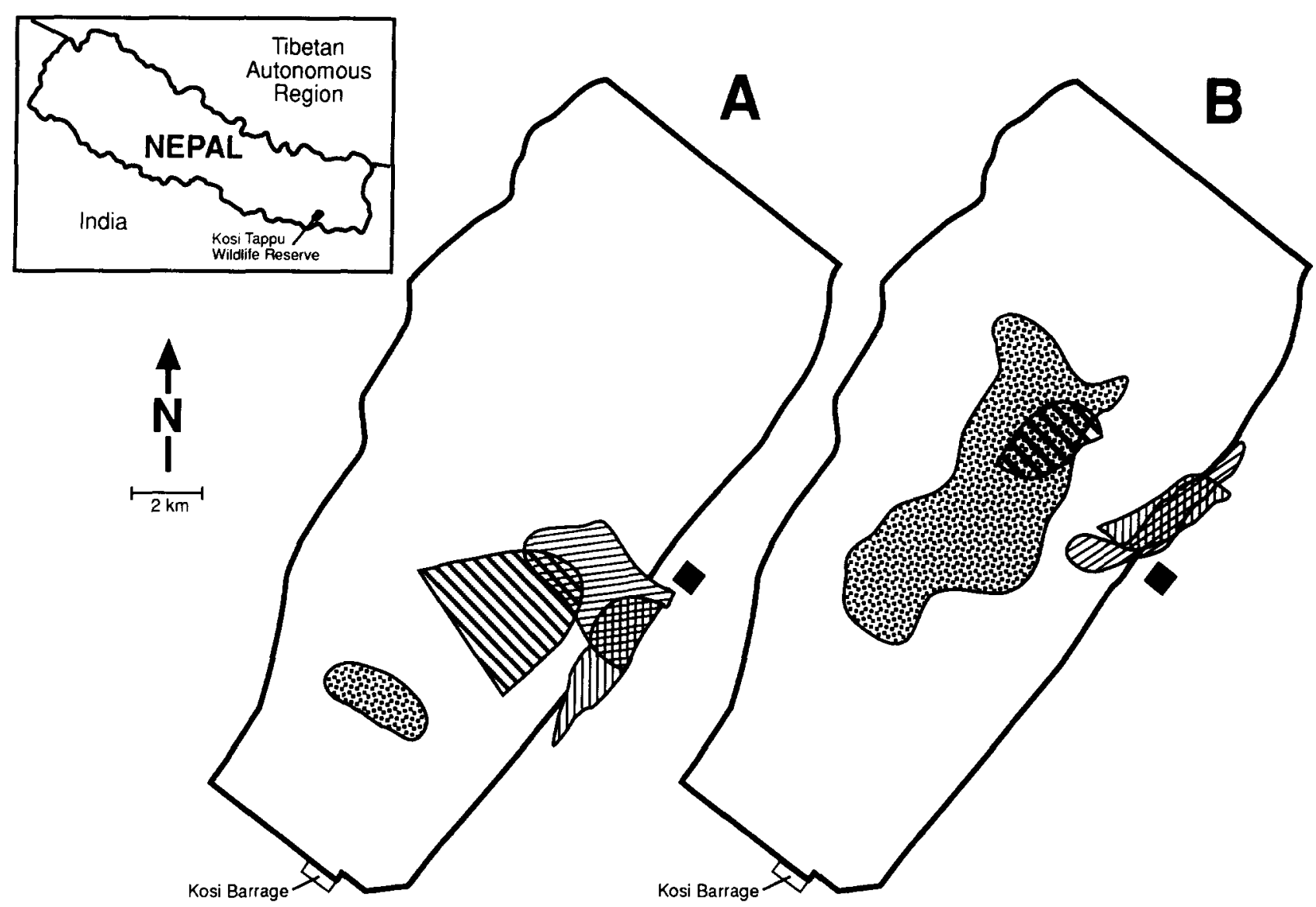

Fig. 1. The approximate home ranges of the south (A) and north (B) mixed (female and offspring) herds during the wet and dry seasons, 1976 and 1987/88. Both herds used areas during the current (1987/88) study which overlapped with those used during the earlier (1976) study (from Dahmer, 1978). Notice that both herds were reported to use areas outside of the reserve during the rainy season in both studies. $\mathrm{O}$, dry season, 1976; $\square$, rainy season, 1976; $\$$, dry season, 1987-88;

, Reserve Headquarters.

each mixed herd. These animals were large and readily identifiable, and were seen on occasion to threaten other males; they presumably got most of the matings. Therefore, $N_{\mathrm{e}}$, which cannot be estimated accurately without reliable paternity data, is predictably lower than the actual (census) population size. However, no matings were observed throughout the course of this study, and the ranges of both mixed herds overlapped with the ranges of bachelor males which could have obtained occasional matings. One immediate effect of inbreeding documented in other studies is a decrease in fecundity over time (Ralls et al., 1986). This appears to be occurring in the Kosi Tappu buffalo population; the instantaneous population growth rate has declined over time, and the ratio of first-year calves to adult females has also declined from 0.61 in 1976 to 0.45 in 1988 (Table 2). However, the population of domestic livestock in the reserve has also increased, and this could decrease fecundity of wild buffalo through densitydependent factors independent of any inbreeding depression. Furthermore, Bhattacharya (1974) reported inter-birth intervals of $<2$ to $>3$ years for domestic water buffalo in a variety of studies, and the first-year calf-to-cow ratios found here are consistent with this range; there are no data on inter-birth intervals or lifetime fecundity in wild water buffalo.

The physical nature of Kosi Tappu is apparently detrimental to long-term conservation of buffalo and other large mammals (Fig. 1). The eastern and western boundaries of the reserve are formed by embankments of the Kosi Project, and are designed to keep floodwaters in to minimize damage to agricultural crops. The northern and southern boundaries are ill-defined and occur within the floodplain of the Kosi River, so that there are no flood refugia for wildlife. Consequently large mammals must leave the reserve and go to agricultural fields during annual floods. The home range data indicate that buffalo spend much of their time during the rainy season outside of the reserve (Fig. 1), and that mixed herds are last to leave, generally waiting until a flood is underway. This apparently resulted in the high calf morality observed here.

An estimated population of over 2000 feral cattle resided in Kosi Tappu during Dahmer's (1978) study. New estimates show that there were at least 7000 cattle in 1988 (T. R. Adhikari, pers. comm.), in addition to at least 130 resident domestic buffalo which were regularly encountered during my field surveys, and were placed in the reserve by their owners to graze and to breed with wild males. Several local buffalo owners interviewed during this study stated that they were able to charge higher prices for male hybrid calves than for domestic calves sold as draught animals in nearby West Bengal, India. 
Several observations suggest that there is little danger of genes from domestic buffalo entering into the wild population: adult domestic males were observed very infrequently in the reserve, and it is unlikely that a domestic male in competition with a wild male could monopolize a wild mixed herd. The presence of livestock, however, could be critical from another standpoint: that of disease. Seidensticker (1975) suggested that disease was the major cause of extirpation of wild water buffalo from what is now Royal Chitwan National Park. Although there is no direct evidence, this seems plausible for several reasons. The animals were never regularly hunted but were extirpated in the early 1960s. This was before Chitwan became a protected area, but after the malaria eradication program which led to massive immigration of people and their livestock into the region (Gurung, 1983). The area is now much better protected since the formation of Royal Chitwan National Park in 1973 (Anon., 1977); although livestock grazing is still a problem in Chitwan (U. R. Sharma, pers. comm.), it is not as severe as in Kosi Tappu.

Because of the concomitant effects of herd structure, a low population size, flood-induced mortality of calves, frequency of contact with domestic animals, and the physical nature of the reserve which does not include the full annual home range of any buffalo herd, the population in Kosi Tappu cannot be considered viable. The flooding problem is expected to increase with time due to massive sedimentation in the Kosi River, which causes it to spill its banks even in moderate floods. An estimated $4 \mathrm{~m}$ of sediment has been deposited on the river bed immediately north of Kosi Barrage since the structure was completed in 1965 (D. V. Jha, pers. comm.). Record damage to the grasslands in Kosi Tappu was observed during the 1987 rainy season through peak flood stages were only slightly over the 20 -year average. One catastrophic event could therefore easily lead to extirpation of wild water buffalo, even if disease and inbreeding do not.

\section{MANAGEMENT OPTIONS}

These findings highlight the need for a restoration program for wild water buffalo in Nepal. This has been previously recommended (Mishra, 1981), but funds have not yet become available. Royal Chitwan National Park offers the best site for reintroduction; it has been declared a World Heritage Natural Site (Thorsell, 1985) and is relatively well-protected. Chitwan has extensive riverine habitat along its northern border and abundant upland habitat of sal Shorea robusta forest which would offer a refuge for buffalo during the rainy season, and therefore should reduce flood-related mortality of calves.

One strategy to reduce any potential inbreeding problems in the founding population would be to introduce groups of females from Kosi Tappu and males from Kaziranga National Park in Assam, India. The governments of India and Nepal have cooperated on restorations in the past (e.g. Indian Rhinoceros, Choudhury, 1985), so this is politically possible. Despite the extreme management problems in Kosi Tappu, removing all wild water buffalo is not advisable because this would be expensive, logistically very difficult, and may foment the local political movement to remove the area from protected status (G. R. Singh, pers. comm.).

Aside from buffalo, Kosi Tappu is extremely important for the conservation of other aspects of biological diversity, especially as staging and wintering habitat for migratory waterfowl (Inskipp \& Inskipp, 1985; Heinen, 1988); it is now included on the United Nations List of Wetlands of International Importance (Anon., 1990). The reserve is also important for the local economy, especially by providing thatch grass and fishing rights to local residents (Heinen, in press). For these reasons, Kosi Tappu should remain a protected area, and the presence of buffalo is likely to ensure this. It may be possible for the Department of National Parks and Wildlife Conservation, in conjunction with the Department of Forestry, to create flood refugia for buffalo and other large mammals because district forest areas are located within $3 \mathrm{~km}$ of the northeastern and $5 \mathrm{~km}$ of the northwestern boundary of Kosi Tappu. Interagency cooperation is critically needed to maintain many large mammal populations because individual management units are generally small (e.g. Salwasser $e t$ al., 1987). However, the creation of corridors may prove politically difficult in this case due to high human population densities in the area, estimated by Anon. (1987) at 274 and 278 people/ $\mathrm{km}^{2}$ along the eastern and western boundaries, respectively (1981 estimates); these are among the highest rural population densities recorded in Nepal.

A socio-economic analysis of costs and benefits to local residents of the Kosi Tappu Wildlife Reserve showed generally poor attitudes about the reserve, but negative attitudes were related to factors such as literacy rate and caste or ethnic group of the household, and not to wealth per se (Heinen, in press). This shows that expanding literacy and providing conservation education programs aimed at local villagers are critically needed to inform people of the reasons for conservation and the benefits they receive from Nepalese reserves (Mishra, 1984). Such socio-political concerns may, due to park-people conflicts (e.g. MacKinnon et al., 1986; Hough, 1988; Lehmkuhl et al., 1988) ultimately be more important for long-term conservation strategies than biological factors. Although all of Nepal's parks and reserves have some conflicts with local people (Heinen \& Kattel, 1992), they are especially acute in Kosi Tappu for several reasons: the reserve is too small to provide adequate year-around habitat for an important target species; the species imposes direct costs to local people by crop destruction; and the region is densely populated. Innovative conservation/development strategies are needed in such cases to ameliorate the competing demands of large mammal conservation and human concerns (e.g. Mwalyosi, 1991). 


\section{ACKNOWLEDGEMENTS}

I thank Mr B. N. Upreti, former Director General of the Department of National Parks and Wildlife Conservation, Nepal, for permitting and encouraging this work. Mr G. R. Singh and Mr T. R. Adhikari, both former wardens of Kosi Tappu Wildlife Reserve, were most helpful in making necessary living and working arrangements; $\mathrm{Mr}$ Singh also helped on numerous occasions recording data and offering encouragement and good humor in the field. Dr P. B. Yonzon, Dr T. Root, Mr B. Kattel and Mr J. N. Mehta read and commented on earlier drafts, and several anonymous reviewers greatly improved the manuscript. This work was supported by the American Peace Corps and by a grant from USAID Biological Diversity Funds. I thank Dr B. Levenson, formerly of the USAID Mission to Nepal, for help in obtaining funding. Last but not least, Mr R. K. Singh served as field assistant throughout the course of the study.

\section{REFERENCES}

Angus, R. A. \& Schultz, R. J. (1983). Meristic variation in homozygous and heterozygous fish. Copeia, 1983(2), 287-99.

Anon. (1977) National Park and Wildlife Conservation Act of 2029 (1973). Official translation. His Majesty's Government Ministry of Law and Justice, Law Books Management Committee, Kathmandu, Nepal.

Anon. (1987). Statistical Yearbook of Nepal, 1987. His Majesty's Government National Planning Commission Secretariat, Central Bureau of Statistics, Kathmandu, Nepal.

Anon. (1990). United Nations list of national parks and protected areas. IUCN, Cambridge.

Bhattacharya, P. (1974). Reproduction. In The husbandry and health of the domestic buffalo, ed. W. R. Cockrill. Food and Agricultural Organization of the United Nations, Rome, pp. 105-58.

Bronson, F. H. (1989). Mammalian reproductive biology. University of Chicago Press, Chicago, Illinois.

Choudhury, A. V. (1985). Distribution of Indian one-horned rhinoceros. Tiger Paper, XII(2), 25-9.

Clutton-Brock, J. (1989). A natural history of domesticated mammals. University of Texas Press, Austin, Texas.

Cockrill, W. R. (ed.) (1974). The husbandry and health of domestic buffalo. FAO, Rome.

Dahmer, T. D. (1978). Status and distribution of the wild Asian buffalo Bubalus bubalis in Nepal. MS thesis, University of Montana, Missoula, Montana.

Dinerstein, E. \& McCracken, G. F. (1990). Endangered greater one-horned rhinoceros carry high levels of genetic variation. Conserv. Biol., 4, 417-22.

Falconer, D. S. (1981). Introduction to quantitative genetics. Longman, New York.

Goodman, D. (1987). The demography of chance extinction. In Viable populations for conservation, ed. M. E. Soulé. Cambridge University Press, Cambridge, pp. 11-34.

Gurung, K. K. (1983). Heart of the jungle. Andre Deutsch, London.

Halder, U. (1973). Ecological aspects of social organization in banteng Bos javanicus and feral buffalo Bubalus bubalis in Java. Int. Congr. Game Biol., 11 th, 159-64.

Heinen, J. T. (1988). Rare and new bird records for Kosi Barrage and Kosi Tapu Wildlife Reserve during winter and spring, 1987. J. Nat. Hist. Mus. (Kathmandu), 10, 23-30.

Heinen, J. T. (in press). Park-people relations in Kosi
Tappu Wildlife Reserve. Nepal: A socioeconomic analysis. Environ. Conserv.

Heinen, J. T. \& Kattel, B. (1992). Parks, people, and conservation: A review of management issues in Nepal's protected areas. Population and Environment, 14, 49-84.

Hough, J. L. (1988). Obstacles to effective management of conflicts between national parks and surrounding human communities in developing countries. Environ. Conserv., 15 129-36.

Inskipp C. \& Inskipp, T. (1985). A guide to the birds of Nepal. Croom Helm, London.

Kuehn, D. W. (1986). Population and social characteristics of the tamarao Bubalus mindorensis. Biotropica, 18, 263-6.

Lehmkuhl, J. F., Upreti, R. K \& Sharma, U. R. (1988). National parks and local development: Grass and people in Royal Chitwan National Park, Nepal. Environ. Conserv., $15,143-8$.

MacKinnon, J., McKinnon, K., Child, G. \& Thorsell, J. (1986). Managing protected areas in the tropics. IUCN, Cambridge.

Mishra, H. R. (1984). A delicate balance: Tigers, rhinoceros, tourists and park management vs the needs of local people in Royal Chitwan National Park. In National pParks, conservation and development, ed. J. McNeeley \& K. R. Miller. Smithsonian Institution Press, Washington, DC, pp. 197 205.

Mishra, P. N. (1981). Wild Asian buffalo. In Wild is beautiful, ed. T. C. Majapuria. Craftman Press, Bangkok, pp. 433-40.

Mwalyosi, R. B. B. (1991). Ecological evaluation for wildlife corridors and buffer zones for Lake Manyara National Park, Tanzania, and its immediate environment. Biol. Conserv., 57, 171-86.

Ralls, K., Harvey, P. H. \& Lyles, A. M. (1986). Inbreeding in natural populations of birds and mammals. In Conservation Biology, ed. M. E. Soulé. Sinauer Associates, Sunderland, Massachusetts, pp. 35-56.

Saharia, V. B. (1982). Wildlife in India. Natraz, Dehra Dun.

Salwasser H., Schonewald-Cox, C. \& Baker, R. (1987). The role of interagency cooperation in managing for viable populations. In Viable populations for conservation, ed. M. E. Soulé. Cambridge University Press, Cambridge, pp. 159-73.

Schaller, G. B. (1977). Mountain monarchs. University of Chicago Press, Chicago, Illinois.

Seidensticker, L. (1975). Ungulate populations in Chitwan Valley, Nepal. Office of Zoological Research, National Zoological Park, Smithsonian Institution, Washington, DC (unpublished report).

Seshadri, B. (1986). India's wildlife and wildlife reserves. Sterling Publishers Private, New Delhi.

Sinclair, A. R. E. (1977). The African buffalo. University of Chicago Press, Chicago, Illinois.

Soulé, M. E. (1980). Thresholds for survival: Maintaining fitness and evolutionary potential. In Conservation biology, ed. M. E. Soulé \& B. Wilcox. Sinauer Associates, Sunderland, Massachusetts, pp. 151-69.

Stainton, J. D. A. (1972). Forests of Nepal. John Murray, London.

Thorsell, J. (1985). World Heritage report-1984. Parks, 10(1), 8-9.

Tulloch, D. G. (1974). Australia. In The husbandry and health of domestic buffalo, ed. W. R. Cockrill. FAO, Rome, pp. 493-505.

Tulloch, D. G. (1978). The water buffalo, Bubalus bubalis, in Australia: Grouping and home range. Aust. Wildl. Res., 5, 327-54.

Tulloch, D. G. (1979). The water buffalo, Bubalus bubalis, in Australia: Reproductive and parent-offspring behavior. Aust. Wildl. Res., 6, 265-87.

Yonzon, P. B. \& Hunter, Jr, M. L. (1991). Conservation of the red panda Ailurus fulgens. Biol. Conserv., 57, 1-11. 